\title{
WHEY PROPERTIES AND ITS USE FOR PRODUCTION OF FUNCTIONAL AND PROBIOTIC DRINKS
}

\author{
Tatjana Kalevska, Zora Uzunoska, Viktorija Stamatovska \& Aleksandar Saveski \\ Faculty of Technology and Technical Sciences, University St. Kliment Ohridski of Bitola \\ Dimitar Vlahov bb, 1400 Veles, Republic of Macedonia \\ e-mail: tkalevska@gmail.com
}

\begin{abstract}
Whey is a by-product in the process of cheese production, represented with $85-90 \%$ from the total milk volume and contains $50 \%$ of the milk's dry matter: lactose, whey proteins, minerals and vitamins. The high quality whey proteins are a source of energy and nutrients, rich with essential amino acids which makes them biologically essential proteins. The healing properties of whey are due to the presence of immunoglobulin and immunologically active substances which strengthen the immune system, protect the organism from different bacterial infections and allergic reactions. Only a small part of the whey produced in dairies in Macedonia is used for the production of albumin cheese, while the rest is left unused. The goal of this work is to show the therapeutic and functional properties of whey as well as the possibility of its use in production of functional and probiotic whey based drinks, with the use of new innovative technologies and scientific findings.
\end{abstract}

Keywords: whey, therapeutic properties, functional properties, functional and probiotic drinks.

\section{INTRODUCTION}

In recent times, we have been facing with a greater and greater lack of food, which is one of the most important factors destabilizing the world in terms of economic balance and survival. Thus, secondary products from the food processing industry are used for the processing and production of quality food products to discourage the wasting of potential foods. The dairy industry is increasingly producing products with higher nutritional and therapeutic properties, including whey based beverages.

\section{WHEY PROPERTIES}

Whey is a by-product, which is obtained in the technological process of cheese and casein production. The annual production of whey at a world level, on average, amounts to 100 million tons, of which about $94 \%$ is obtained as a by-product in the process of cheese production, and only about $6 \%$ is obtained during the process of casein production [1].

Whey, which is obtained in the manufacture of cheese may be acidic and sweet depending on the method of coagulation of casein. The acid whey is formed by acid treatment of the

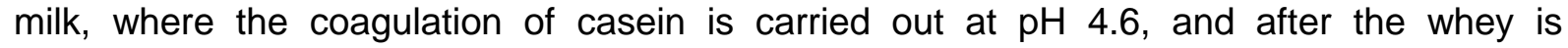
separated from curd, while the sweet whey is produced by enzymatic treatment of the milk (chymosin), and the whey is separated after the formation and filtering of the curd. During the coagulation process of casein, only $20 \%$ is utilized for the production of cheese, while about $80 \%$ of it is whey, which further represents a major problem in the dairy industry [2].

The composition and properties of whey are quite variable and depend on the technology of production, as well as the quality of milk [11]. On average, whey contains $94 \%$ water and about $50 \%$ dry matter that passes from the milk into the whey. The bulk of the whey is composed of lactose, and less than $1 \%$ are whey proteins. [2]. The amount of mineral matter in whey varies the most and depends on the technological procedure for the production of cheese, and the greatest variations are in the amount of calcium, phosphorus, lactic acid and lactates [6].

IRTIIE Vol. 6, No. 1, 2018 ISSN 1314-8788 (print), ISSN 1314-8796 (online), doi: 10.15547/artte.2018.01.008 
Table 1. The average chemical composition of sweet and acid whey (g/l) [6]

\begin{tabular}{|l|c|c|}
\hline Composition & Sweet whey & Acid whey \\
\hline total dry matter & $63.0-70.0$ & $63.0-70.0$ \\
\hline lactose & $46.0-52.0$ & $44.0-46.0$ \\
\hline proteins & $6.0-10.0$ & $6.0-8.0$ \\
\hline calcium & $0.4-0.6$ & $1.2-1.6$ \\
\hline phosphates & $1.0-3.0$ & $2.0-4.5$ \\
\hline lactates & 2.0 & 6.4 \\
\hline chloride & 1.1 & 1.1 \\
\hline
\end{tabular}

Whey is rich in water-soluble vitamins, and the most common are riboflavin, cobalamin and folic acid. The yellow-green color of whey is the result of the greater content of riboflavin [8, 11]. The protein content in the acid and sweet whey is similar. During the process of cheesemaking under the influence of acids and enzymes, the whey proteins are completely transferred to the whey because they do not coagulate. In the composition of the whey proteins, there are various thermo labile fractions such as: $\alpha$-lactoalbumins, $\beta$-lactoglobulins, blood serum albumins, immunoglobulins, glycoproteins (lactoferrin, transferrin), enzymes (lysozyme, lacto peroxidase) which are important factors of the immuno-active composition of whey with antimicrobial properties which can reduce or inhibit allergic reactions.

The healing properties of whey are attributed to the presence of immunoglobulin's and the immuno-active composition of the resistance-protecting enzymes, protecting the body from harmful bacteria, viruses and infectious disease agents, and reducing or inhibiting allergic reactions [10].

Whey proteins are nutritionally the most valuable proteins because of their amino acid composition, that is, the greater proportion of essential amino acids, the most common being lysine, cysteine and methionine. Due to their amino acid composition, whey proteins have a higher biological value compared to casein, and daily requirements for most essential amino acids can be obtained by consuming 1.5 liters of whey [8].

Table 2. Essential amino-acids (g/100g of proteins) of casein and lactalbumin [11]

\begin{tabular}{|l|c|c|l|c|c|}
\hline Amino acid & Casein & Lactoalbumin & Amino acid & Casein & Lactoalbumin \\
\hline triptophane & 1.3 & 2.2 & cisteine & 0.38 & 3.4 \\
\hline treonine & 4.3 & 5.2 & metionine & 3.1 & 2.3 \\
\hline isoleucine & 6.6 & 6.2 & fenilalanin & 5.4 & 4.4 \\
\hline leucine & 10.0 & 12.3 & tirosine & 5.8 & 3.8 \\
\hline lizine & 8.0 & 9.1 & valine & 7.4 & 5.7 \\
\hline
\end{tabular}

Whey proteins are rich in amino acids such as isoleucine, leucine, and valine, which, unlike other essential amino acids, are directly metabolized and transmitted into the muscle tissue in which they participate in tissue construction during exercise and stamina training [13]. The higher utilization of whey proteins is closely related to the cysteine/methionine ratio, which is about 10 times greater in whey than that of casein, as is indicated by the fact that heatdenatured lactalbumins are almost completely (100\%) utilized in the digestive system, compared to casein, out of which about $75 \%$ is used. Whey proteins also have good functional properties, like: good solubility, viscosity, gelling ability, and emulsification, which are used in the food industry because of which their concentrates (for increasing the nutritional value of dairy and other food proteins, and because of the higher digestibility of whey protein) are used in food production for infants [12].

The utilization of whey means to processing in accordance with a certain technological procedure, whereby the components of whey as a by-product can be used to produce quality 


\section{ART'TE

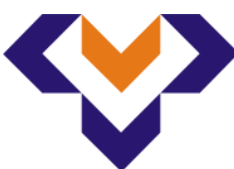 \\ Ipplied Resseirlohes in Technics, Technologies and Bductation \\ Journal of the Faculty of Technics and Technologies, Trakia University https://sites.google.com/a/trakia-uni.bg/artte/}

food products, which will be used in the diet of people, and at the same time stopping, wasting, or rather utilization of potential food and preventing environmental pollution.

Whey is mainly processed into products that do not require expensive technological processes. The bulk of it is manufactured into whey powder as well as concentrates and isolates as ingredients of individual proteins and lactose [15]. In the Republic of Macedonia, only a small part of the whey that is obtained as a by-product in the technological process of cheese production is utilized and processed into albumin cheese - cottage cheese, while the other part that is not processed is a danger to the environment because it is most often discharged into the drains. The technological process of obtaining albumin cheese is the simplest way of utilizing and processing of whey, in which the denaturation of the whey protein is achieved by gradually heating the whey at a high temperature over $92-95^{\circ} \mathrm{C}$.

\section{BEVERAGES BASED ON WHEY}

The most economical way for full utilization of the potentials of whey is the processing and production of fermented beverages based on whey, which due to their nutritional and biological properties can completely replace the traditional functional and probiotic beverages produced by milk. Fermented whey based beverages can be functional and probiotic, and due to their content of full-fat proteins, these beverages represent an ideal source of energy and nutrients. In the manufacture of whey based fermented drinks strater cultures are used, mainly lactic acid bacteria. To improve the taste of whey based fermented beverages, aromatization is done with the addition of fruit juice or fruit aroma, and they are sweetened with the addition of fructose [11]. In the production of whey based probiotics, in addition to lactic acid bacteria, some types of probiotic bacteria from the genus Bifidobacterium also participate in fermentation, whereby fermented probiotic beverages are obtained with desirable nutritional and sensory properties, which are beneficial for the health of people [4]. During the fermentation of the whey ingredients, various functional substances such as lactic acid, acidic acid, bioactive peptides, exopolysaccharides, $\beta$-galactosidase are obtained, which have a significant influence on the human organism [9].

The value of whey as a therapeutic drink and its beneficial effect on the human body, were emphasized by the father of medicine Hippocrates, 460 years b.c. Nowadays the modern man $s$ more and more aware of the importance and role of whey in the everyday diet. Fermented and probiotic whey beverages are intended for different categories of people: seniors, children, athletes, overweight people, people that make sure they have a proper and balanced diet, and others. The advantage of the whey probiotic beverages are the therapeutic effects of probiotics on human health, such as: lowering blood pressure, lowering cholesterol, lowering the risk of bowel cancer, stimulating the immune system, alleviating lactose intolerance, and so on [14]. One of the important factors affecting the quality of probiotic whey products is the selection of probiotic strains from which the sensory properties of the beverages depend, and the richness of high-proteins is an ideal source of energy and nutrients. Many clinical trials have proven that probiotic, and especially functional fermented drinks act antihypertensive and reduce blood pressure [5].

In addition to the functional and probiotic beverages, whey can be used to produce soft drinks belonging to the group of dietary beverages and alcoholic beverages based on whey. The soft drinks of whey include: dietary supplements with the addition of sweeteners with high energy value of $104-113 \mathrm{~kJ} / \mathrm{ml}$, dietary supplements with hydrolyzed lactose which can be supplemented with: fruit, fruit juices, various sugars, cereals, isolates from proteins of plant origin, $\mathrm{CO}_{2}$, chocolate, cocoa, vanilla and other flavored supplements and powdered drinks that have good instant properties enriched with vitamins and minerals, with a long shelf life and good solubility. Citrus and tropical fruits such as: lemon, banana, papaya, mango, are most commonly added in the whey based soft drinks, that manage to cover up

\section{IRTIIE Vol. 6, No. 1, 2018 ISSN 1314-8788 (print), ISSN 1314-8796 (online), doi: 10.15547/artte.2018.01.008}




\section{ARTTE $Y^{2}$}

Ipplied Resseirlohes in Technics, Technologies and Bductation

Journal of the Faculty of Technics and Technologies, Trakia University https://sites.google.com/a/trakia-uni.bg/artte/

the unwanted scent of whey, as well as the sour-salted flavor [3]. Because of the high lactose content of about $70 \%$ in the dry matter, whey is a good raw material to produce alcoholic beverages such as: whey beer and wine (champagne), which have a low alcoholic percentage up to $1,5 \%$ [10]. For the fermentation of lactose from whey, the most commonly used types of yeasts are Kluyveromyces or kefir culture.

\section{CONCLUSION}

Whey is a by-product that is obtained in the technological process of cheese production, whose composition and properties depend on the technology of production and quality of the milk used. Because of its amino acid composition, whey proteins have high biological value and greater digestibility compared to casein.

Whey is a product of great potential, which should be used in the processing of fermented functional and probiotic products with retained therapeutic and functional properties and the necessity of its inclusion in the daily diet of people. By using whey as a by-product, wasting of potential food and environmental pollution will be prevented.

\section{REFERENCES}

[1] Affersholt T.(2007). Market developments and industry challenges for lactose and lactose derivatives, IDF Symposium „Lactose \& Its Derivates“, Moscow, 2007.

[2] Beucler J., Drake M., Foegeding E.A.(2005). Design of a beverage from Whey permeate, J. Food Sci. 70 (2005) 277 -285.

[3] Đurić, M., Carić, M., Milanović, S., Tekić, M., Panić, M. (2004). Development of whey based beverages, European Food Research and Technology, 219, (2004).321-328.

[4] Đukić Vuković A.J., Mojović Lj.V., Pejin D., Vukašinović- Sekulić M., Rakin M., Nikolić S., J.Pejin, (2011). Novi pravci i izazovi u proizvodnji mlečne kiseline na obnovljivim sirovinama, Hem. Ind. 65 (2011) 103-114.

[5] Huth, P.J., Dirienzo, D.B., Miller, G.D. (2006). Major Scientific Advances with Dairy Foods in Nutrition and Health, Journal of Diary Science, 89 (2006). 1207-1221.

[6] Jelen P.(2003). Whey Processing, in: H. Rginski, J.F. Fuquau, P.F. Fox (Eds.), Encyclopedia of Dairy Sciences, Vol. 4, Academic Press - An Imprint of Elsevier, Boston, London, (2003), p. 2740.

[7] Jeličić I, Božanić R, Tratnik Lj. (2008). Napitci na bazi sirutke - nova generacija mliječnih proizvoda. Mljekarstvo 58 (3) (2008). 257-274,

[8] Popović-Vranješ, A., Vuičić, I.F. (1997).Tehnologija sirutke, monografija. Poljoprivredni fakultet, Novi Sad (1997). [2] Stanzer D., Stehlik-Tomas V., Zetić Gulan V., Manenica J.(2002). Sirutka-alternativna sirovina za proizvodnju prehrambenog kvasca, Mljekarstvo 52 (2002) 113-124.

[9] Tamime A.Y., Božanić R., Rogelj I. (2003). Probiotički fermentirani mliječni proizvodi, Mljekarstvo 53 (2003) 111-134.

[10] Tratnik, Lj. (1986). Ulo.ga sirutke u dojenačkoj hrani, Prehrambeno-tehnološka i biotehnološka revija, 24 (2-3). (1986). 139-144.

[11] Tratnik LJ.(1998).Mlijeko - tehnologija, biokemija i mikrobiologija, Hrvatska mljekarska udruga, Zagreb, 1998.

[12] Tratnik LJ.. (2003). Uloga sirutke u proizvodnji funkcionalne mliječne hrane, Mljekarstvo 53 (2003) 325-352.

[13] Sherwood S., Jenkins D.(2007). Carbonated protein drink and method of making, U.S. Pat. US 2007/0178214 A1, (2007).

[14] Shah N. (2007). Functional cultures and health benefits. International Diary Journal, 17, (2007). 1262-1277.

IRTIIE Vol. 6, No. 1, 2018 ISSN 1314-8788 (print), ISSN 1314-8796 (online), doi: 10.15547/artte.2018.01.008 